\title{
Pulmonary surfactant function in alveoli and conducting airways
}

\author{
GORAN ENHORNING MD PhD \\ Department of Gynecology/Obstetrics, State University of New York at Buffalo, Buffalo, \\ New York, USA
}

G ENHORNING. Pulmonary surfactant function in alveoli and conducting airways. Can Respir J 1996;3(1):21-27.

Surface tension plays a very important role in aeration of the neonate's lungs. Pulmonary surfactant, which is inadequate in the premature infant, modifies surface tension during the act of breathing and is necessary for maintenance of alveolar stability. These facts led to the development of the concept that it might be possible to treat the premature infant by supplementing the infant's inadequate surfactant supply. In addition to maintaining alveolar stability, pulmonary surfactant might also be of vital importance for maintenance of small airway patency. Various conditions, most importantly asthma, might be the reason for a surfactant dysfunction to develop. This in turn might cause airway resistance to increase.

Key Words: Airway resistance, Alveolar stability, Asthma, Cystic fibrosis, Pneumonia, Small airway patency

\section{Fonction du surfactant dans les alvéoles et les voies de conduction}

RÉSUMÉ : La tension de la surface alvéolaire joue un rôle important dans l'aération des poumons du nouveau-né. Le surfactant, qui est déficient chez l'enfant prématuré, modifie la tension de la surface alvéolaire pendant la respiration et est indispensable au maintien de la stabilité alvéolaire. Ces observations ont permis de développer le concept selon lequel il pourrait être possible de traiter l'enfant prématuré en supplémentant sa réserve insuffisante de surfactant. En plus de maintenir la stabilité alvéolaire, le surfactant pourrait être d'une importance vitale pour le maintien de la perméabilité des petites voies aériennes. Plusieurs affections, surtout l'asthme, pourraient favoriser le développement d'une dysfonction du surfactant avec pour conséquence une augmentation éventuelle de la résistance des voies aériennes. pulmonologist, von Neergaard, who lived in Switzer-
land during the first half of this century, suspected that
since the expanded lung has such a large air-liquid interface,
surface tension would likely be of great importance for respira-
tory function. He speculated that when the neonate initially in-
hales air into its lungs, surface tension could be expected to offer
great resistance to lung expansion. To test this hypothesis he
compared the pressure required to expand atelectatic lungs with
air and with a liquid. He found, as he had suspected, that much more pressure had to be exerted when the lungs were expanded with air, and he explained very clearly how surface tension was the reason for this difference (1).

\section{AERATION OF NEONATAL LUNGS AS AFFECTED BY SURFACE TENSION}

During the newborn infant's first breath there will be hemispherical air-liquid interfaces, menisci, moving down 


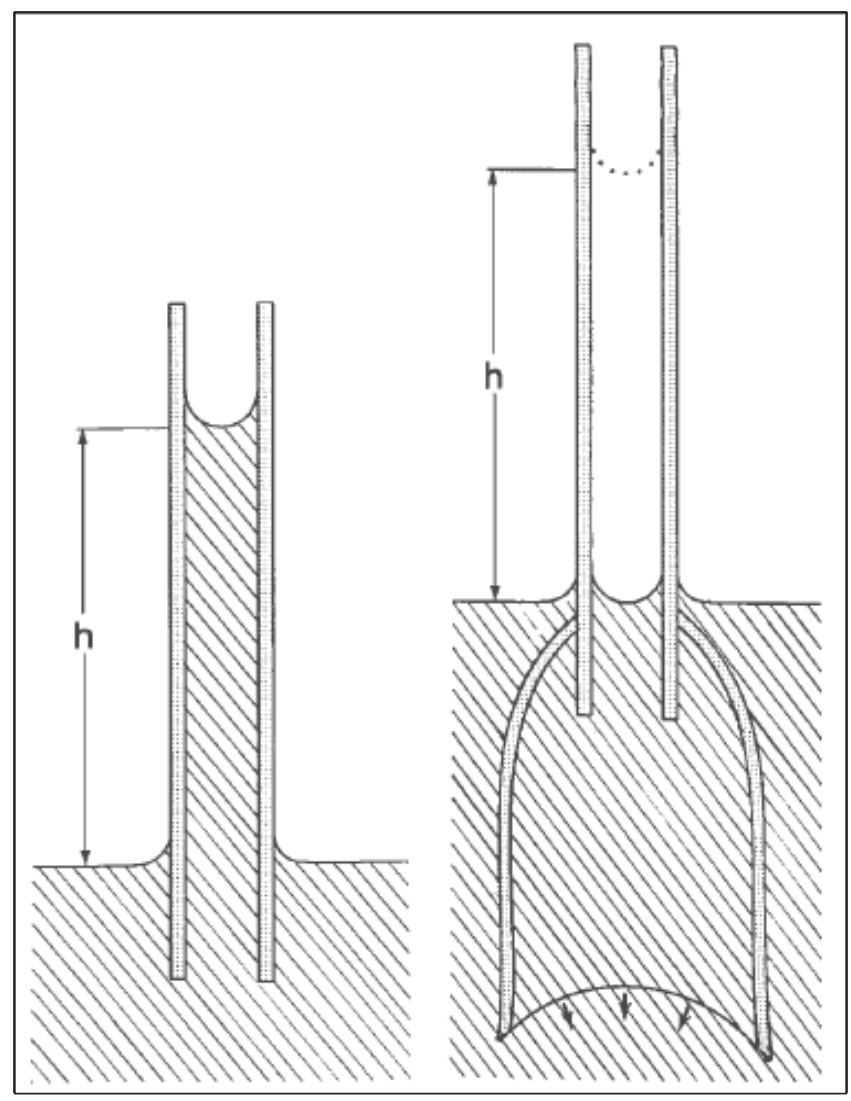

Figure 1) (Left) Classical way of determining surface tension is to measure the height to which a liquid will rise in a capillary with

known radius. (Right) By enclosing the lower end of the capillary and lowering pressure in the enclosure the liquid can be made to move down to the surrounding liquid whereby the effect of gravity is abrogated

through the conducting airways. Since the airway of the lung is hydrophilic, as a glass capillary is, the concavity of the meniscus is facing the air, and surface tension of the airway liquid, $\gamma$, acting along the inner circumference of the airway, is opposing a movement of the meniscus towards the alveoli. For this reason an evaluation of surface tension in the neonate's airway liquid is of interest.

\section{CAPILLARITY}

Capillarity is a classical method to evaluate surface tension. Its principle is demonstrated in Figure 1 (left). If the end of a vertical glass capillary with a known radius, $\mathrm{R}$, is lowered below the surface of the liquid to be studied, the liquid will rise to a certain height, h. Surface tension of the liquid is then in balance with the weight of the liquid column. If the lower end of the capillary is enclosed in a chamber in which pressure can be accurately lowered, the meniscus can be made to move down to the level of the surrounding liquid (Figure 1, right). The meniscus remains at this level, where the effect of gravity has been abrogated, only because there is a pressure difference, $\Delta \mathrm{P}$, across the surface of the meniscus. $\Delta \mathrm{P}$, acting over the inner cross section of the capillary, $\pi \mathrm{R}^{2}$, constitutes the force, $\Delta \mathrm{P} \pi \mathrm{R}^{2}$, holding the meniscus at this level and it is counteracted by $\gamma 2 \pi \mathrm{R}$, the force exerted by surface tension, $\gamma$, along the inner circumference of the capil- lary. This derives the equation $\Delta \mathrm{P} \pi \mathrm{R}^{2}=\gamma 2 \pi \mathrm{R}$ which can be simplified to $\Delta \mathrm{P}=2 \gamma / \mathrm{R}$, which is the law of Laplace as it applies to a spherical surface.

When surface tension of the neonate's airway liquid has been determined, the law of Laplace would seem to make it possible to calculate the pressure difference, $\Delta \mathrm{P}$, required to force the air-liquid interface to pass the most narrow section of the conducting airway. Once the meniscus has passed that section the alveolus would become expanded with air. However, the radius of the narrow section of the airway, $\mathrm{R}$, would have to be known, and if surface tension of the airway liquid were to be determined with the method illustrated in Figure 1 , only the value of the equivalent surface tension would be known, ie, the value pertinent to a surface area not changing in size.

\section{SURFACE TENSION AFFECTED BY PULMONARY SURFACTANT}

Surface tension of the mature neonate's airway liquid is reduced by surfactant originating from type II alveolar cells. Pulmonary surfactant consists of about $85 \%$ phospholipids (2), amphipathic molecules characterized by having a polar head which is hydrophilic, whereas the fatty acids, at the other end of the molecule, are decidedly hydrophobic. Because the molecule is partly explicitly hydrophobic it cannot be completely surrounded by water molecules; the fatty acids must stay away from the water and they will if they adjoin the fatty acids of other phospholipid molecules. This is probably the reason that the molecules, as they are synthesized, form typical arrangements in the moist cytoplasm of type II cells. They are known as lamellar bodies and consist of concentric bilayer shells, layered one outside the other.

Between the phospholipid molecules, composing the bilayers of the lamellar bodies, are also the surfactant associated proteins, nominated surfactant protein (SP)-A, SP-B, SP-C and SP-D (3). In the last 10 years they have been the focus of an enormous investigative activity. However, their function is still not completely clear, although two of them, SP-B and SP-C, are known to be essential since they promote rapid adsorption - a fast formation of a phospholipid monolayer at an air-liquid interface (4-9). Clark et al (10) strongly support the functional importance of SP-B. When the gene for this apoprotein was disrupted in mice, lamellar bodies did not form in a normal manner in the fetal type II cells and, in spite of postnatal respiratory efforts, the lungs did not become expanded and the neonates succumbed. There are also reports that surfactant proteins $\mathrm{A}, \mathrm{B}$ and $\mathrm{C}$ counteract the surfactant inhibiting effect of plasma proteins (11) and that SP-A helps combat airway infection $(12,13)$. There are several excellent reviews on the molecular biology, structure and function of the apoproteins $(8,9,14)$.

The equivalent surface tension will be very much affected by an expansion (or a compression) of the surface area at which a monolayer has formed. As the meniscus of the airway is moving in the direction of the alveoli during the initial aeration there is a continuous expansion of the conducting airway's air-liquid interface. The adsorbance of amphipathic 


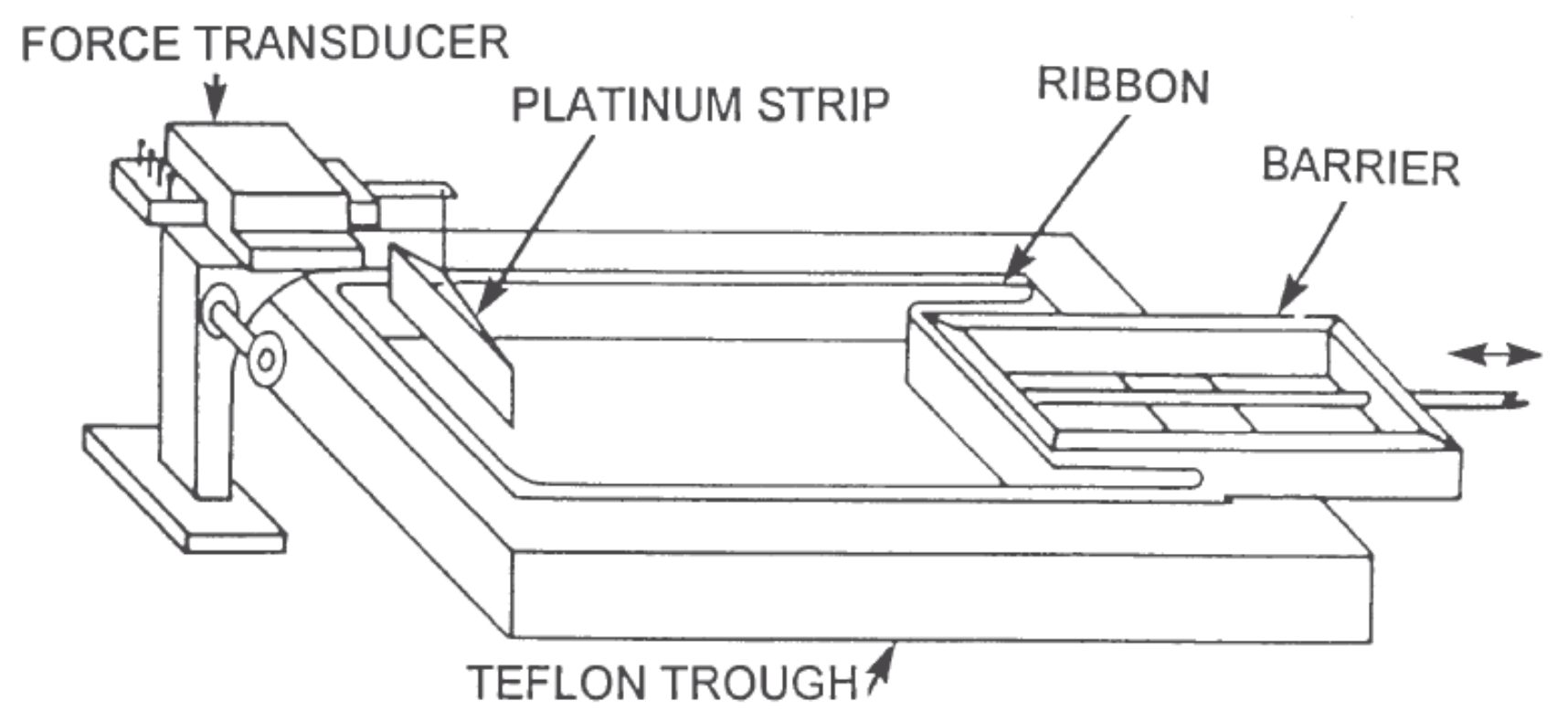

Figure 2) The Wilhelmy balance as used by Clements for his pioneering evaluation of how a monomolecular layer of pulmonary surfactant will affect surface tension when it is rhythmically compressed and expanded, as during breathing. Reproduced from reference 18 with permission of the author

molecules to this expanding surface area may not be quick enough to keep up the number of molecules that would be present at the surface under equivalent conditions. The intermolecular distance would then be greater, resulting in a higher value of surface tension. Once the alveolus becomes aerated the surface area is vastly increased and when breathing has been established there will be a regular oscillation of the surface area: a compression during expiration and an expansion during inspiration.

The law of Laplace, $\Delta \mathrm{P}=2 \gamma / \mathrm{R}$, makes it clear that if surface tension, $\gamma$, remains at a fixed value, $\Delta \mathrm{P}$ would increase during expiration when the alveolar radius, $\mathrm{R}$, is diminishing. This would mean that for the alveolus to remain expanded during expiration, it has to be surrounded by a pressure which becomes more negative as the alveolar radius diminishes. However, it is well known that during expiration transmural pressure is diminishing. Furthermore, the alveoli will not all be of the same size, and those that are smallest are at the greatest risk of collapsing since they require to be surrounded by a greater negative pressure to remain expanded. These inadequacies made it clear to Pattle $(15,16)$ and Clements $(17,18)$ that surface tension could not remain at a fixed value throughout the respiratory cycle.

Thirty-five years ago there were several established methods to measure surface tension, but Clements saw the need for a method to evaluate how surface tension was affected when a film, formed at the air-liquid interface, was rhythmically compressed and expanded. Using the modified Wilhelmy balance (Figure 2) he demonstrated very conclusively that lung lavage fluid, when spread over the surface of a Langmuir trough, will show a much lower value of surface tension when the surface area is compressed than when it is expanded (18). From this observation he drew the conclusion that when the surface area is being compressed, as in alveoli during expiration, surface tension will be lowered, a phenomenon he suggested would be an 'anti-atelectasis factor'. The value of $\Delta \mathrm{P}$ might then diminish during expiration, such that the need for a negative intrapleural pressure to maintain alveolar expansion would gradually be reduced. When the alveolar surface area is expanding, as it will be during inspiration, surface tension increases and if augmented more than the radius, the value of $\Delta \mathrm{P}$ will increase.

\section{PULMONARY SURFACTANT}

The reason that amphipathic molecules cause surface tension to change when surface area is compressed or expanded has been the subject of many studies. A current report gives an excellent review of the most recent concepts (19). The amphipathic molecule is characterized by having a polar head which is hydrophilic while the opposite end is hydrophobic, and for that reason will be attracted to air. The major component $(68.5 \%)$ of pulmonary surfactant is diacylphosphatidylholine and more than half of that phospholipid has two palmitic acids constituting the molecule's hydrophobic end (2). This gives the molecule the full name of dipalmitoylphosphatidylcholine (DPPC).

Palmitic acid is a 16-carbon chain which is straight since it has no double bonds. For this reason DPPC molecules can be very tightly packed, and when the surface area is compressed, forcing the molecules to come even closer together, this is mechanically resisted. A high surface pressure, $\pi$, develops which will have a significant influence on surface tension, since $\gamma_{\mathrm{a}}=\gamma_{\mathrm{w}}-\pi$, where $\gamma_{\mathrm{a}}$ is the actual surface tension and $\gamma_{\mathrm{w}}$ is surface tension of water $(72 \mathrm{mN} / \mathrm{m})$. With pulmo- 


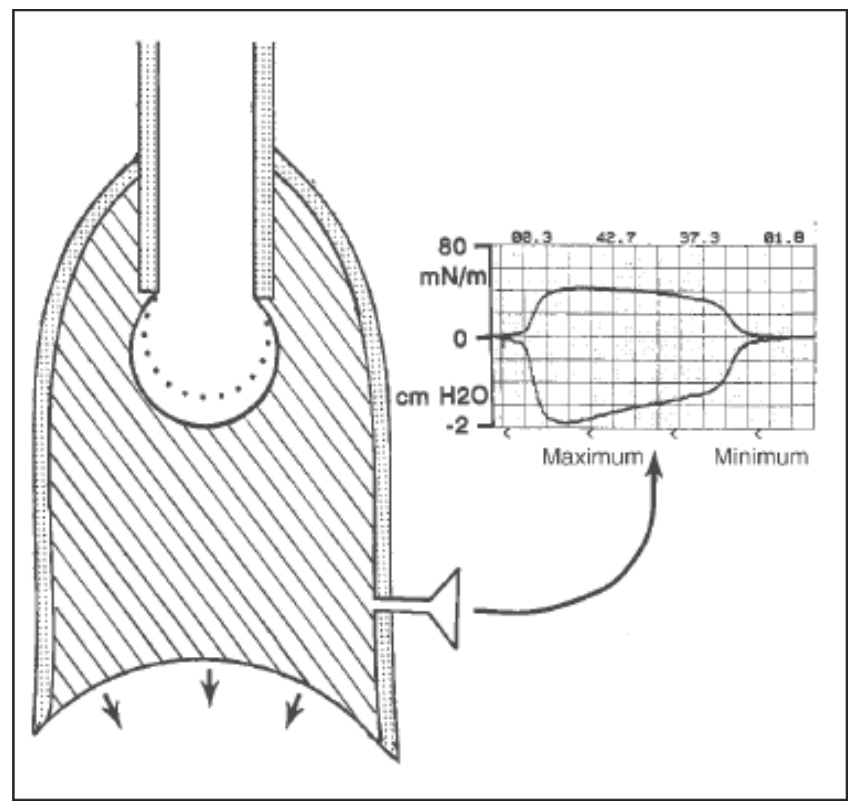

Figure 3) The pulsating bubble surfactometer is a development of the method shown in Figure 1. By forming a bubble at the tip of the capillary and oscillating the liquid volume in the enclosure the bubble is made to pulsate. By recording the pressure that is surrounding the bubble, and by knowing how the bubble radius is alternating, a continuous recording of surface tension can be obtained

nary surfactant a surface pressure of $72 \mathrm{mN} / \mathrm{m}$ readily develops with even moderate compression. One can thus anticipate that at end expiration surface tension will be lowered to close to $0 \mathrm{mN} / \mathrm{m}$, particularly in the alveoli that underwent the greatest reduction in size. That would restrain the smallest alveoli from collapsing.

\section{PREVENTION AND TREATMENT OF RESPIRATORY DISTRESS SYNDROME WITH SURFACTANT}

Clements used the Wilhelmy balance for an evaluation of pulmonary surfactant (18). A chemical analysis showed him (20) that a major component consisted of DPPC, and when he studied that phospholipid alone, dissolved in hexane, he found, after the hexane had evaporated, that the monolayer of DPPC would exert very high surface pressure just as pulmonary surfactant would. Based on that observation Clements hypothesized (21) that, since it had been shown that premature infants developing the respiratory distress syndrome (RDS) had a surfactant deficiency (22), it might be possible to prevent and treat RDS by supplying DPPC to the airways. He organized a clinical trial which was carried out in Singapore. DPPC alone turned out not to be an effective treatment (21) probably because its adsorbance is extremely slow. Nevertheless, the concept - to supply surfactant the premature infant was missing - appeared to be correct. If instilled into the airways before the infant takes its first breath, the surfactant might prevent RDS, a condition which largely develops as a vicious circle. The surfactant instillation might preclude RDS from ever being induced.
Enhorning and Robertson (23) carried out studies on premature rabbit neonates delivered by caesarean section on the 27 th day of gestation. At that gestational age the fetuses are very immature and surfactant synthesis has not yet been initiated. Before the neonates had taken their first breath, pulmonary surfactant was instilled into the trachea, whereas nothing was given to the controls. The surfactant was obtained by lavaging the lungs of adult rabbits and concentrated by centrifugation. The first study (23) was very encouraging and with a series of continued studies in rabbits (24-27) and monkeys $(28,29)$ it was demonstrated that, when natural surfactant is instilled into the trachea or the pharynx of the premature neonate, preferably before the first breath, survival rate, blood gases and chest radiograms improved quite dramatically compared with data from control neonates. It could be concluded that surfactant treatment of the premature neonate is indeed effective. However, the crude natural surfactant used for these studies was not sterile and contained about $10 \%$ protein for which reasons it could not be used for human neonates. With any method of sterilization it lost its surface activity, probably because of the high protein content.

Under the leadership of Possmayer (30) the crude surfactant was transformed to a preparation that appeared to be acceptable for clinical use. The lipids were extracted and resuspended in saline solution. Initially this was felt to lead to a complete removal of proteins. However, it turned out that two lipophilic apoproteins had not been removed but had stayed with the lipids during the extraction procedure. This was a fortunate mistake, since the apoproteins, later nominated SP-B and SP-C (3), have subsequently been shown to be of crucial importance by securing fast adsorption (4-10).

With the extraction procedure the protein content was lowered to 1 to $2 \%$, which was the likely reason that sterilization by autoclaving could be carried out without loss of surface activity. Further animal studies (31) with this sterilized preparation offered convincing evidence that the preparation, called calf lung surfactant extract by Notter et al (32), was appropriate for human use. One controlled and randomized trial was carried out in Toronto (33) and one in Buffalo (34). They both supported the concept that RDS of the neonate can be prevented and treated by a supplementation of the premature infant's inadequate supply of endogenous surfactant. However, the first study pointing to this possibility had been published five years earlier by Fujiwara et al (35).

\section{IN VITRO METHODS FOR A STUDY OF SURFACTANT FUNCTION}

The Wilhelmy method yielded valuable information concerning the function of pulmonary surfactant. However, it had its clear limitations, and in an attempt to simulate more closely the in vivo situation the pulsating bubble surfactometer was constructed (36). It was conceived as a model of an alveolus (Figure 3). At the lower end of a vertical capillary a bubble is expanded in a chamber holding the liquid to be studied. By forcing the bubble to oscillate from a fixed maximal to a fixed minimal size as the pressure around the bubble, 
and thereby the value of $\Delta \mathrm{P}$, is recorded, surface tension, $\gamma$, can be calculated according to the law of Laplace, $\gamma=\Delta \mathrm{PR} / 2$. Since $\mathrm{R}$, the radius, changes according to a certain program, from a maximum of $0.55 \mathrm{~mm}$ to a minimum of $0.4 \mathrm{~mm}$, a microprocessor can be programmed so that, as the information about the value of $\Delta \mathrm{P}$ comes in, $\gamma$ can be calculated and continuously recorded. A digital printout of the value of $\gamma$ can also be obtained when the bubble is of maximal $\left(180^{\circ}\right)$ and of minimal size $\left(0^{\circ}\right)$ and when the cycle is at $90^{\circ}$ and $270^{\circ}$.

The pulsating bubble surfactometer has the advantage of requiring only a small sample (the sample chamber has a volume of $25 \mu \mathrm{L}$ ); cleaning is easy since the sample chamber is disposable; rate of pulsation can vary from 0 to 99 and can thus simulate the rate of breathing; temperature can be controlled from $+5^{\circ} \mathrm{C}$ to $+50^{\circ} \mathrm{C}$; and with the addition of the Hypophase Exchanger the liquid surrounding an active monolayer can be replaced. However, the pulsating bubble surfactometer also has its limitations. The phospholipids of the surfactant preparation studied must be at a relatively high concentration, usually at least $1 \mathrm{mg} / \mathrm{mL}$. Furthermore, there is the possibility that the monolayer is not only at the surface of the bubble, but is also extruded into the vertical capillary where it would line its inner wall.

It is a distinct possibility that surfactant is indeed extruded into the vertical capillary, but if that happens it is likely that the wall of the capillary eventually becomes saturated, and that would impede further extrusion of the bubble monolayer. That assumption was supported by experiences with the Hypophase Exchanger. An active preparation of pulmonary surfactant was studied, and when the recording showed that an active surfactant monolayer had formed and was lining the bubble, the liquid surrounding it was replaced with saline solution. This could be done repeatedly without a significant change of the surface tension recording. If there had been a continued loss of the monolayer to the capillary the tracing would indicate a loss of activity since surfactant molecules from the hypophase could no longer be replaced. To avoid the possibility of a monolayer loss to the capillary, Schürch (37) has made a modification of the pulsating bubble surfactometer which allows him to study a 'captive bubble'. He has also developed an interesting technique to evaluate the surface tension existing inside the airways (38).

\section{SURFACTANT IN THE CONDUCTING AIRWAY}

A surfactant monolayer is quite likely to be extruded from the surface of the bubble but probably also from the surface of the alveolus. If that did not occur, it is unlikely that the narrow conducting airway would be lined by a surface monolayer, since the site of surfactant synthesis is the alveolar type II cell. However, a surfactant monolayer has clearly been demonstrated with electron microscopy $(39,40)$ and it has been suspected that it is required for the proper function of the conducting airway (41-43). Lately, an in vitro model of the conducting airway has provided evidence that pulmonary surfactant may secure the patency of a narrow glass tube, and therefore most likely will also secure patency of the most narrow section of a conducting airway $(44,45)$. A recent publica-

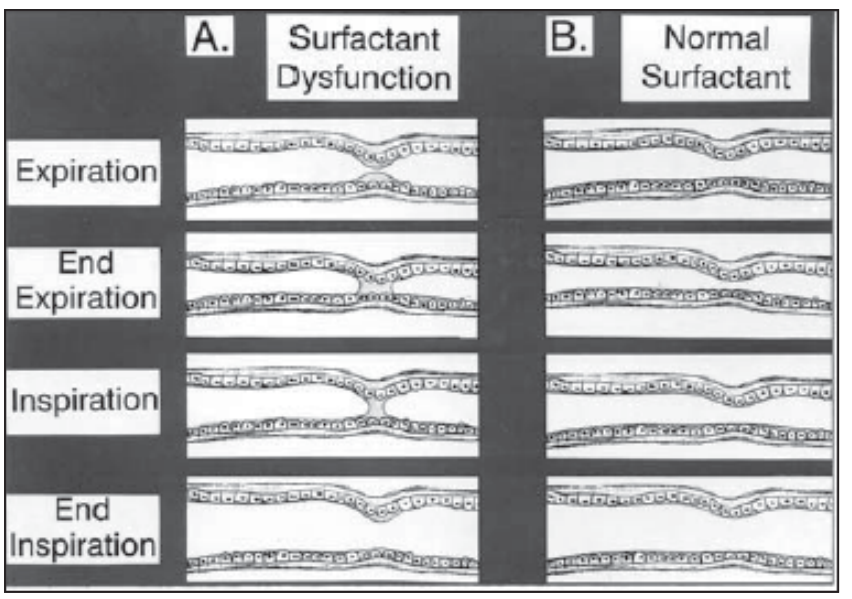

Figure 4) Without the function of pulmonary surfactant there is a risk that at least during part of the respiratory cycle a small airway will become blocked by liquid (A). With pulmonary surfactant airway patency is secured $(B)$

tion reports that pulmonary surfactant will maintain patency of the rat's conducting airway (46).

\section{SURFACTANT FUNCTION IN THE CONDUCTING AIRWAY}

Figure 4 illustrates how surfactant might function in the terminal conducting airway. If surfactant is missing, or for some reason is inhibited in its function, the small amount of liquid lining the inner wall of the airway will be attracted to the airway's most narrow part; there is then the risk that during expiration, when the width of the terminal conducting airway is reduced, the moist surface on one side will touch that on the other and a column of liquid will form to block the lumen of the airway completely. The law of Laplace as it applies to a cylindrical surface, $\Delta \mathrm{P}=\gamma / \mathrm{R}$, may explain this course of events. Where the airway lumen is most narrow, its radius, $\mathrm{R}$, will have the lowest value. Consequently, $\Delta \mathrm{P}$ would have the highest value in the most narrow section, if $\gamma$ had the same value in all sections of the airway. $\Delta \mathrm{P}$ is the pressure difference across the air-liquid interface. Since pressure in the air is very close to being identical in adjacent parts of an open airway, the most negative pressure in the liquid lining the airway would be in the most narrow part. This would attract more liquid to that section so that a blocking column of liquid eventually might form.

Well functioning pulmonary surfactant will prevent the formation of a blocking liquid column. This has been demonstrated experimentally, and can be explained in the following way. When a monolayer of surfactant has formed at the airliquid interface it will become compressed at the most narrow section as liquid is accumulating in that section. The compression gives a high value of surface pressure, $\pi$, which will reduce the value of $\gamma$ in the most narrow section. If $\gamma$ is reduced more than the radius is, pressure in the liquid lining the most narrow section would no longer be less than it is in liquid lining other parts of the airway, and there would be no at- 

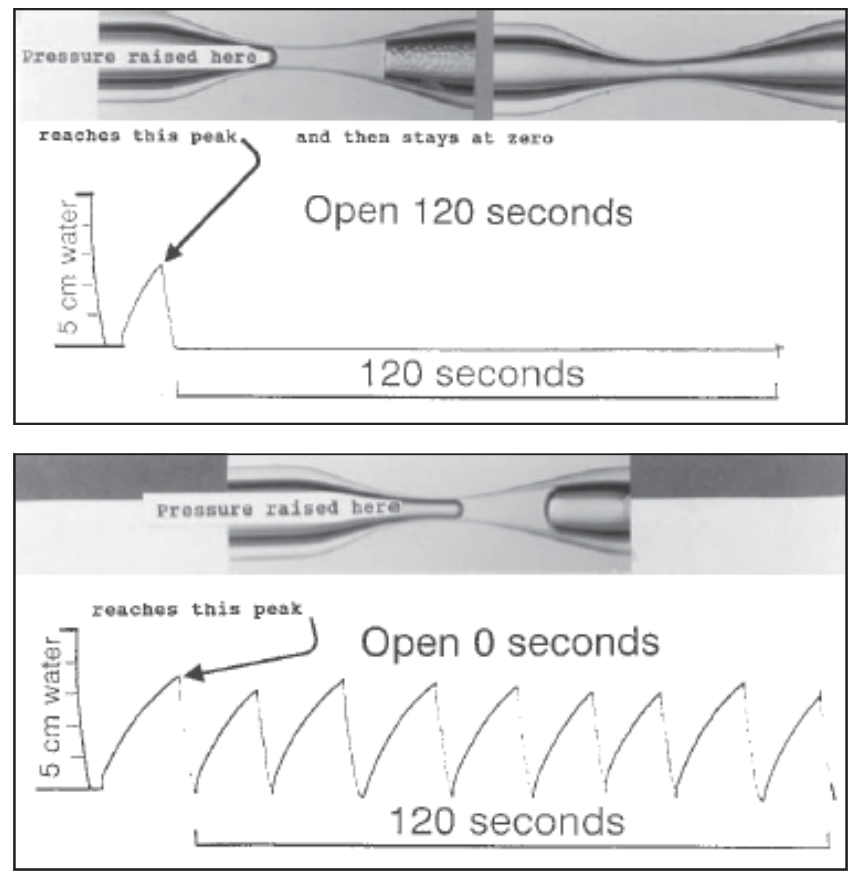

Figure 5) A glass capillary is conceived as a model of a narrow conducting airway. In a constricted section of the capillary a small volume $(0.5 \mu \mathrm{L})$ of the liquid to be tested is instilled. (Top) When pressure is raised on one side of the liquid it is extruded and will not return if it contains well functioning surfactant. (Bottom) Dysfunctioning surfactant will return and will not retain openness of the capillary during the 120 sincerely recording period.

traction of liquid to the most narrow section; the airway would remain patent.

\section{THE CAPILLARY}

As a model of the surfactant function in a terminal conducting airway an in vitro system has been developed (Figure 5). It consists of a glass capillary containing a short section which has been made very narrow (inner diameter $0.2 \mathrm{~mm}$ ). In that narrow section $0.5 \mu \mathrm{L}$ of the liquid to be studied is deposited. The liquid forms a column blocking the lumen. When pressure is raised on one side of the column the liquid will move out of the narrow section just as a flow of air through the lungs' airways will force liquid to move out of narrow sections where it might have accumulated. The question is: will the liquid return to the narrow section or will the airway remain patent? The pressure required to extrude the liquid out of the narrow section is recorded. If the liquid tested is a well functioning pulmonary surfactant, it will not return and a pressure of zero will be recorded for the full time of recording, $120 \mathrm{~s}$ after the liquid was first extruded so that pressure dropped to zero (Figure 5, top). If the surfactant is partly inhibited and thus not functioning optimally, pressure will drop as just described, but within the $120 \mathrm{~s}$ of recording, liquid will return and cause pressure to be increased again. This may be repeated several times and as a consequence pressure will not be at zero for the full $120 \mathrm{~s}$ period. If the surfactant is functioning very poorly, or if the liquid tested consists of water or a pure liquid such as acetone or chloroform, pressure will be raised as soon as it has dropped to zero and it will never remain at zero during the $120 \mathrm{~s}$ period of recording. The capillary is then seen to be closing repeatedly with formation of new liquid columns, time of openness being defined as zero (Figure 5, bottom).

What causes surfactant to lose its ability to maintain patency? Contamination with plasma proteins is a likely and common reason. Such a contamination will occur when there is a leakage of plasma proteins into the lumen of the conducting airway. This will occur during an inflammation, perhaps caused by an asthma attack, which today is recognized as being an inflammatory reaction (47-50). Plasma proteins may also leak into the airway lumen during RDS or when an inflammation is caused by air pollution or by an infection, such as a viral or bacterial pneumonia, or one complicating cystic fibrosis.

Surfactant might also become inactivated by the action of hydrolyzing enzymes. Phospholipase $\mathrm{A}_{2}\left(\mathrm{PLA}_{2}\right)$, released from macrophages and mast cells, hydrolyzes DPPC into free palmitic acid and lysophosphatidylcholine. Another enzyme, lysophospholipase (PLB), would obtain the necessary substrate from the PLA2 hydrolysis. PLB has been shown to be released from eosinophils $(51,52)$; during an asthma attack in an ato pic individual it is likely that large quantities of PLB will be released, since eosinophilia is one of the characteristics of the allergic reaction. Another indication that PLB is released in amounts so enormous that the enzyme falls out as crystals, is the fact that Charcot-Leyden crystals have been found to consist of PLB as the sole protein $(51,52)$.

ACKNOWLEDGEMENTS: Supported by grant HL 49971 from the National Heart, Lung, and Blood Institute of the National Institutes of Health.

\section{REFERENCES}

1. von Neergaard, K. Neue Auffassungen über einen Grundbegriff der Atemmechanik. Die Retraktionskraft der Lunge, abhängig von der Oberflächenspannung in den Alveolen. Z Gesamte Exp Med 1929;66:373-94.

2. Possmayer F, Yu S-H, Weber JM, Harding PGR. Pulmonary surfactant. Can J Biochem Cell Biol 1984;62:1121-31.

3. Possmayer, F. A proposed nomenclature system for pulmonary surfactant-associated proteins. Am Rev Respir Dis 1988;138:990-8.

4. Takahashi A, Fujiwara T. Proteolipid in bovine lung surfactant function. Biochem Biophys Res Commun 1986;135:527-32.

5. Whitsett JA, Hull WM, Ohning B, Ross G, Weaver TE. Immunological identification of a pulmonary surfactant associated protein of molecular weight $=6000$ Daltons. Pediatr Res 1986;20:744-9.

6. Yu S-H, Possmayer F. Reconstitution of surfactant activity by using the $6 \mathrm{kDa}$ apoprotein associated with pulmonary surfactant. Biochem J 1986;236:85-9.

7. Curstedt T, Jörnvall H, Robertson B, Bergman T, Berggren P. Two hydrophobic low molecular mass protein fractions of pulmonary surfactant: characterization and biophysical activity. Eur J Biochem 1987;168:255-62.

8. Weaver TE, Whitsett JA. Function and regulation of expression of pulmonary surfactant-associated proteins. Biochem J 1991;273:249-64. 
9. Whitsett JA, Baatz JE. Hydrophobic surfactant proteins SP-B and SP-C: Molecular biology, structure and function. In: Robertson B, van Golde LMG, Batenburg JJ, eds. Pulmonary Surfactant: From Molecular Biology to Clinical Practice. Amsterdam: Elsevier Science Publishers BV, 1992:55-75.

10. Clark JC, Wert SE, Bachurski CJ. Targeted disruption of the surfactant protein B gene disrupts surfactant homeostasis, causing respiratory failure in newborn mice. Proc Natl Acad Sci USA 1995;92:7794-8.

11. Venkitaraman AR, Hall SB, Whitsett JA, Notter RH. Enhancement of biophysical activity of lung surfactant extracts and phospholipid-apoprotein mixtures by surfactant protein. Chem Phys Lipids 1990;56:185-94.

12. van Iwaarden JF, Welmers B, Verhoef J Haagsman HP, van Golde LMG. Pulmonary surfactant protein A enhances the host-defence mechanism of rat alveolar macrophages. Am J Respir Cell Mol Biol 1990;2:91-8.

13. Jacquelien CP, Voorhout WF, van Golde LMG, Verhoef J, Van Strijp JAG, van Iwarden JF. Opsonic activities of surfactant proteins $\mathrm{A}$ and $\mathrm{D}$ in phagocytosis of Gram-negative bacteria by alveolar macrophages. J Infect Dis 1995;172:481-9.

14. Hawgood S. The hydrophilic surfactant protein SP-A: molecular biology, structure and function. In: Robertson B, van Golde LMG, Batenburg JJ, eds. Pulmonary Surfactant: From Molecular Biology to Clinical Practice. Amsterdam: Elsevier Science Publishers BV, 1992:33-54.

15. Pattle RE. Properties, function and origin of the alveolar lining layer. Nature 1955;175:1125-6.

16. Pattle RE. Properties, function and origin of the alveolar lining layer. Proc R Soc Lond 1958;148B:217-40.

17. Clements JA. Surface tension of lung extracts. Proc Soc Exp Biol Med 1957;95:170-2.

18. Clements JA. Surface phenomena in relation to pulmonary function. Physiologist 1962;5:11-28.

19. Jones MN, Chapman D. Micelles, Monolayers, and Biomembranes. New York: Wiley-Liss, 1995:24-63.

20. Klaus MH, Clements JA, Havel RJ.Composition of surface-active material isolated from beef lungs. Proc Natl Acad Sci USA 1961;47:1858-9.

21. Chu J, Clements JA, Cotton EK, Klaus MH, Sweet AY, Tooley WH. Neonatal pulmonary ischemia. Pediatrics 1967;40:709-66.

22. Avery ME, Mead J. Surface properties in relation to atelectasis and hyaline membrane disease. Am J Dis Child 1959;97:517-23.

23. Enhorning G, Robertson B. Lung expansion in the premature rabbit fetus after tracheal deposition of surfactant. Pediatrics 1972;50:58-66.

24. Enhorning G, Grossman G, Robertson B. Tracheal deposition of surfactant before the first breath. Am Rev Respir Dis 1973;107:921-7.

25. Robertson B, Enhorning G. The alveolar lining of the premature newborn rabbit after pharyngeal deposition of surfactant. Lab Invest 1974;31:54-9.

26. Enhorning G, Robertson B, Milne E, Wagner R. Radiological evaluation of the premature rabbit neonate after pharyngeal deposition of surfactant. Am J Obstet Gynecol 1975; $121: 475-80$.

27. Wallin A, Burgoyne R, Enhorning G. Oxygen consumption of the newborn rabbit treated with pulmonary surfactant. Biol Neonate 1977;31:245-51.

28. Enhorning G, Hill D, Sherwood G, Cutz E, Robertson B, Bryan C. Improved ventilation of prematurely delivered primates following tracheal deposition of surfactant. Am J Obstet Gynecol 1978;132:529-35.

29. Cutz E, Enhorning G, Robertson B, Sherwood G, Hill D. Hyaline membrane disease: effect of surfactant prophylaxis on lung morphology in premature primates. Am J Pathol 1978;92:581-94.
30. Metcalfe IL, Enhorning G, Possmayer F. Pulmonary surfactant-associated proteins: their role in the expression of surface activity. J Appl Physiol 1980;49:34-41.

31. Metcalfe IL, Pototschnik R, Burgoyne R, Enhorning G. Lung expansion and survival in rabbit neonates treated with surfactant extract. J Appl Physiol 1982;53:838-43.

32. Notter RH, Egan EA, Kwong MS, Holm BA, Shapiro DL. Lung surfactant replacement in premature lambs with extracted lipids from bovine lung lavage: effects of dose, dispersion technique, and gestational age. Pediatr Res 1985;19:569-77.

33. Enhorning G, Shennan A, Possmayer F, Dunn M, Chen CP, Milligan J. Prevention of neonatal respiratory distress syndrome by tracheal instillation of surfactant: a randomized clinical trial. Pediatrics 1985;76:145-53.

34. Kwong MS, Egan EA, Notter RH, Shapiro DL. Double-blind clinical trial of calf lung surfactant extract for the prevention of hyaline membrane disease in extremely premature infants. Pediatrics 1985;76:585-92.

35. Fujiwara T, Maeta H, Chida S, Morita T, Watabe Y, Abe T. Artificial surfactant therapy in hyaline membrane disease. Lancet 1980;i:55-9.

36. Enhorning G. Pulsating bubble technique for evaluating pulmonary surfactant. J Appl Physiol 1977;43:198-203.

37. Schürch S, Bachofen H, Goerke J, Possmayer F. A captive bubble method reproduces the in situ behavior of lung surfactant monolayers. J Appl Physiol 1989;67:2389-96.

38. Schürch S, Bachofen H, Weibel ER. Alveolar surface tension in excised rabbit lungs: effect of temperature. Respir Physiol 1985;62:31-45.

39. Gil J, Weibel ER. Extracellular lining of bronchioles after perfusion-fixation of rat lungs for electron microscopy. Anat Rec 1971;169:185-200.

40. Gehr P, Schürch S, Berthiaume Y, Im Hof V, Geiser M. Particle retention in airways by surfactant. J Aerosol Med 1990;3:27-43.

41. Macklem PT, Proctor DF, Hogg JC. The stability of peripheral airways. Respir Physiol 1970;8:191-203.

42. Kamm RD, Schroter RC. Is airway closure caused by a liquid film instability? Respir Physiol 1989;75:141-56.

43. Yager D, Butler JB, Bastacky J, Israel E, Smith G, Drazen JM. Amplification of airway constriction due to filling of airway interstices. J Appl Physiol 1989;66:2873-84.

44. Liu M, Wang L, Li E, Enhorning G. Pulmonary surfactant will secure free airflow through a narrow tube. J Appl Physiol 1991;71:742-8

45. Enhorning G, Holm BA. Disruption of pulmonary surfactant's ability to maintain openness of a narrow tube. J Appl Physiol 1993;74:2922-7.

46. Enhorning G, Duffy LC, Welliver RC. Pulmonary surfactant maintains patency of conducting airways in the rat. Am J Respir Crit Care Med 1995;151:554-6.

47. Chung KF. Role of inflammation in the hyperreactivity of the airways in asthma. Thorax 1986;41:657-62.

48. Persson CGA, Erjefält I. Inflammatory leakage of macromolecules from the vascular compartment into the tracheal lumen. Acta Physiol Scand 1986;126:615-6.

49. Kay AB. Asthma and inflammation. J Allergy Clin Immunol 1991;87:892-910.

50. O'Byrne PM. Airway inflammation and the pathogenesis of asthma. Can Respir J 1994;1:189-95.

51. Weller PF, Goetzl EJ, Austen KF. Identification of human eosinophil lysophospholipase as the constituent of Charcot-Leyden crystals. Proc Natl Acad Sci USA 1980;77:7440-3.

52. Weller PF, Bach D, Austen KF. Human eosinophil lysophospholipase: the sole protein component of Charcot-Leyden Crystals. J Immunol 1982;128:1346-9. 


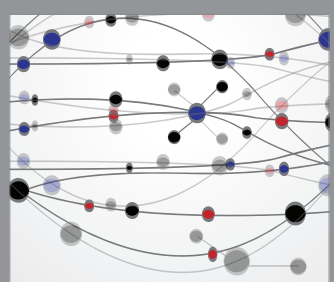

The Scientific World Journal
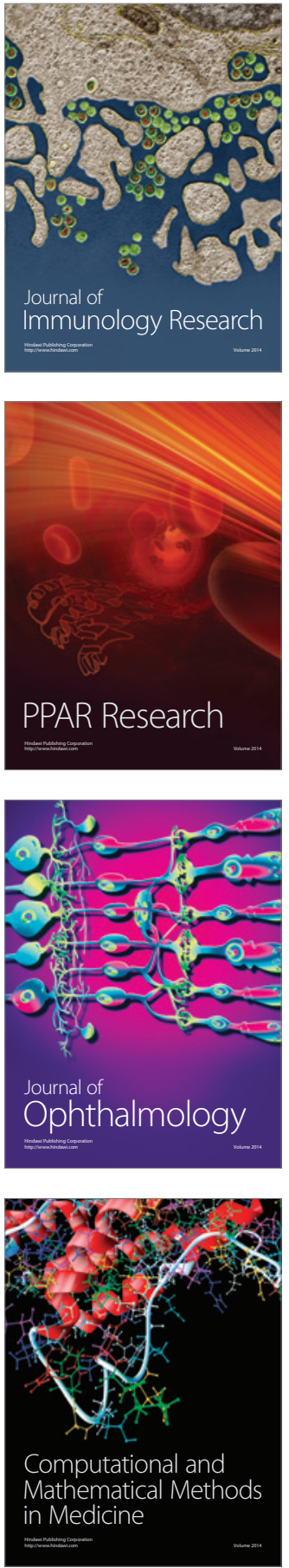

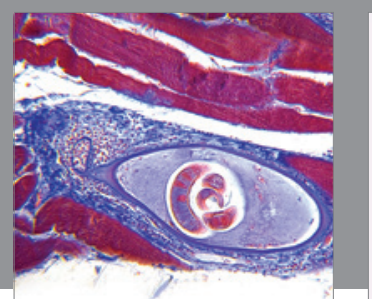

Gastroenterology Research and Practice

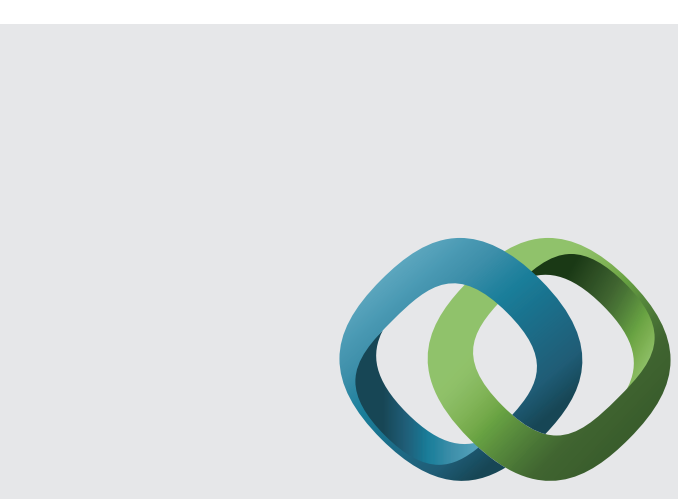

\section{Hindawi}

Submit your manuscripts at

http://www.hindawi.com
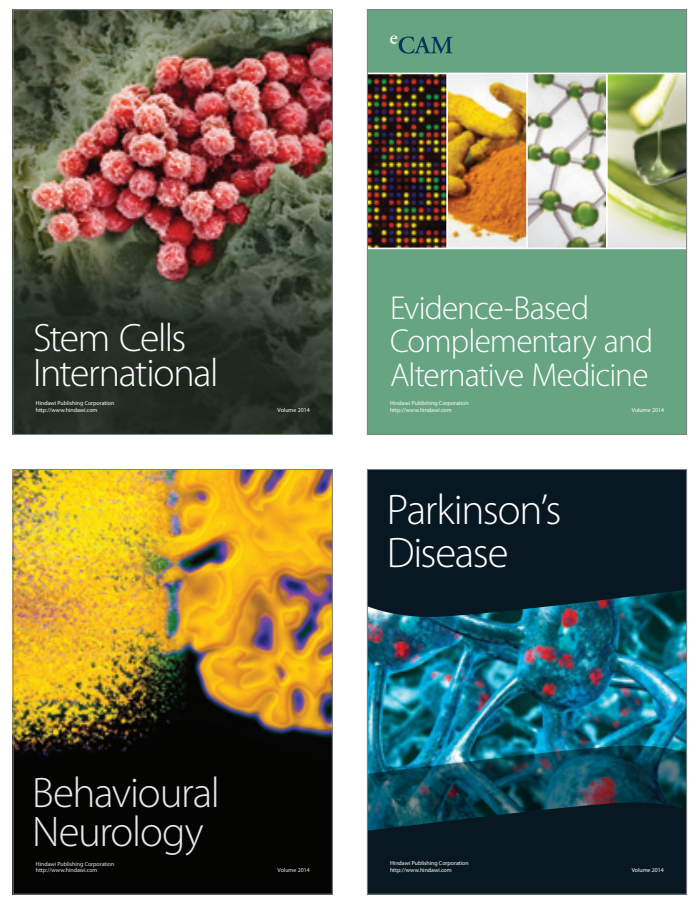
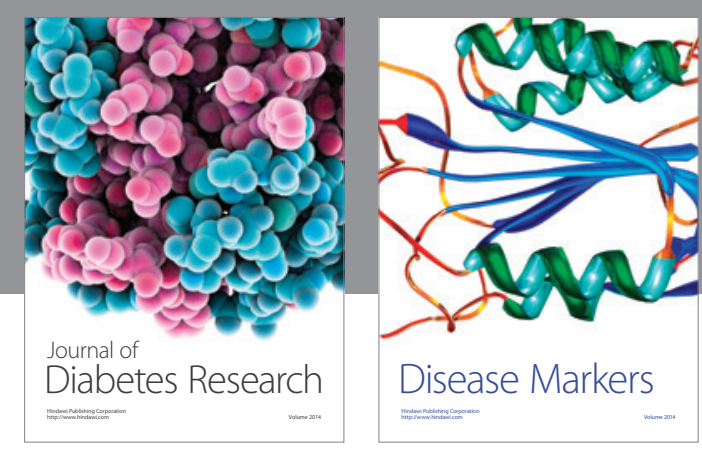

Disease Markers
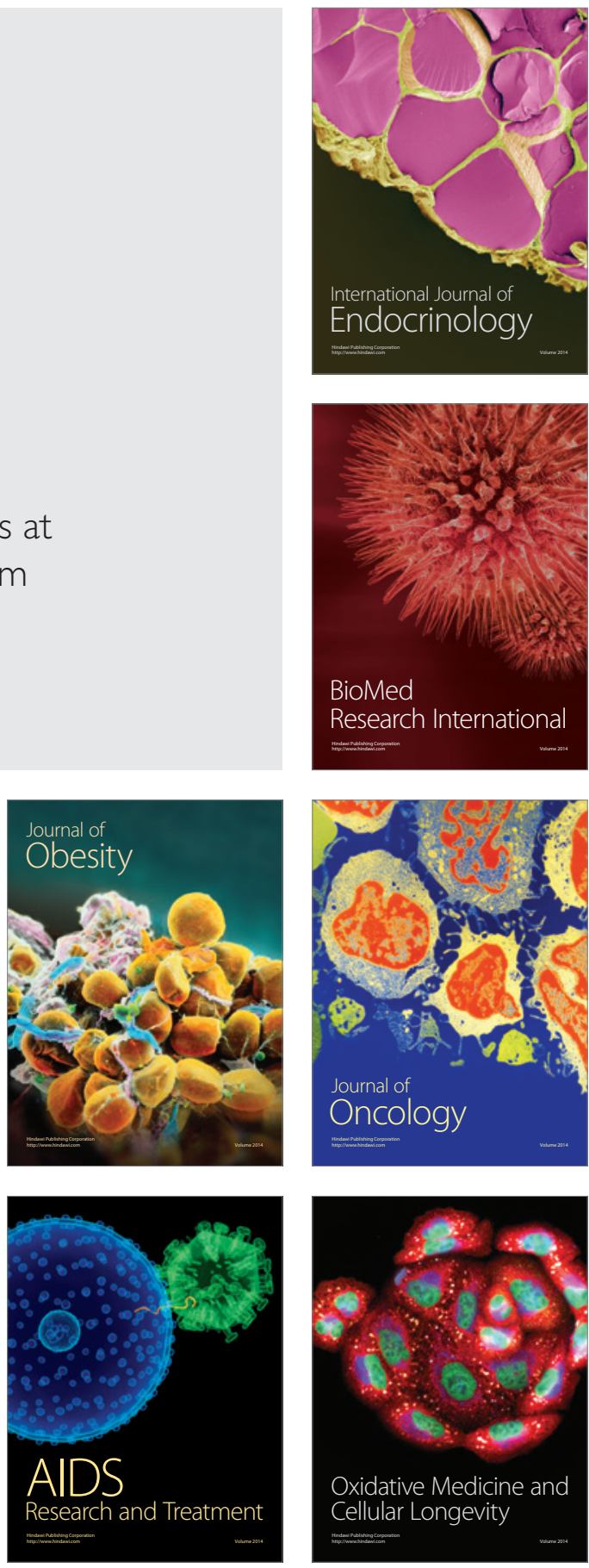